\title{
The evolution and performance of river basin management in the Murray- Darling Basin
}

\author{
Andrew Ross $^{1}$ and Daniel Connell ${ }^{1}$
}

\begin{abstract}
We explore bioregional management in the Murray-Darling Basin (MDB) in Australia through the institutional design characteristics of the MDB River Basin Organization (RBO), the actors and organizations who supported and resisted the establishment of the RBO, and the effectiveness of the RBO. During the last 25 years, there has been a major structural reform in the MDB RBO, which has changed from an interstate coordinating body to an Australian government agency. Responsibility for basin management has been centralized under the leadership of the Australian government, and a comprehensive integrated Basin plan has been adopted. The driving forces for this centralization include national policy to restore river basins to sustainable levels of extraction, state government difficulties in reversing overallocation of water entitlements, the millennium drought and its effects, political expediency on the part of the Australian government and state governments, and a major injection of Australian government funding. The increasing hierarchy and centralization of the MDB RBO does not follow a general trend toward multilevel participative governance of RBOs, but decentralization should not be overstated because of the special circumstances at the time of the centralization and the continuing existence of some decentralized elements, such as catchment water plans, land use planning, and water quality. Further swings in the centralization-decentralization pendulum could occur. The MDB reform has succeeded in rebalancing Basin water allocations, including an allocation for the environment and reduced diversion limits. There are some longer term risks to the implementation of reform, including lack of cooperation by state governments, vertical coordination difficulties, and perceived reductions in the accountability and legitimacy of reform at the local level. If implementation of the Basin plan is diverted or delayed, a new institution, the Commonwealth Environmental Water Holder, can play a major role in securing and coordinating environmental water supplies.
\end{abstract}

Key Words: centralization; coordination; environment; management; river basin organization; stakeholders

\section{INTRODUCTION}

The Murray-Darling Basin (MDB) in Australia is widely considered to be a success story in river basin management (Kemper et al. 2005). The MDB institutions have been put forward as a model for other countries in dealing with challenges such as salinity, nutrient pollution, and allocation of scarce water between competing uses. In response to these challenges, natural resource management and water policy in the MDB has been integrated and framed with a bioregional approach at the scale of catchments (sub-basins). Basin-wide coordination has been provided by intergovernmental agreements, and specialized river basin organizations were established to manage the agreements. In many respects, the management of the MDB has been a success story, but in other respects, it has been less successful and new challenges have emerged. These include the contested nature of sustainable water resource development limits and consumptive and environmental water allocations, and implementation of basin-wide goals at the catchment level (Connell and Grafton 2011).

The bioregional river basin management approach in the MDB parallels a more general global trend to manage water resources and set up water management structures at the river basin level (Teclaff 1996, Mostert 2003). More than 400 international treaties and organizations govern 263 river basins in 145 countries on five continents (Kauffman 2015). The management of water resources at the basin scale has been explained by the perceived failure of previous institutions, including lack of recognition of program interdependency at the basin scale, lack of coordination and cooperation between institutions, management settings that favor special interest groups such as farmers and industry, and limited active public participation (Schlager and Blomquist 2000). In more wealthy countries, there has been a trend for river basin planning and management to evolve toward coordinating bodies, configured to accommodate local scales and processes and the diversity of stakeholders and interests (Molle 2009). This trend has also been observed in the Murray-Darling Basin, but recently there has been some recentralization of MDB governance.

Two issues can be raised about the institution and operation of river basin organizations. Firstly, decision-making arrangements can be based on consensus or hierarchical decision-making. Consensus carries the risk of gridlock, whereas hierarchy can result in lack of ownership or exploitation of weaker stakeholders and the environment (Schlager and Blomquist 2000). Secondly, authority can be unitary within a single river basin authority or pluralistic. A unitary authority can be subject to "bureaucratic pathologies" (Biswas 2004), and it has been suggested that multilevel river basin governance with a patchwork of institutions at overlapping levels is not only feasible but more desirable (Huitema et al. 2009). Despite the widespread advocacy and implementation of the bioregional river basin approach, there is limited evidence on the effectiveness of river basin management or on political dimensions of the design and implementation of river basin management organizations. Three questions can be raised about river basin organizations: what are their institutional design characteristics, who supported and resisted their creation and reform, and how have they performed.

We explore these questions using a case study of institutional and political aspects of river basin management in the MurrayDarling Basin. We focus on river basin management in the MDB since the Murray-Darling Basin Agreement in 1992 and the establishment of the Murray-Darling Basin Commission 
(MDBC). This period can be divided into two parts: management under the MDB Agreement between 1992 and 2007, and subsequent management under the provisions of the 2008 Intergovernmental Agreement on the MDB and the 2012 MurrayDarling Basin Plan. In this case, the river basin organization (RBO) includes several components: a political or policy-making body, an executive, an administrative body, and a stakeholder consultative body. The design and functions of the first three components of the RBO were substantially changed in 20072008. While our main focus is on water management and the RBO, reference is also made to parallel developments in natural resource management and catchment management.

This article is based on original analysis of Australian and state legal and other government documents, consultant reports, academic papers, and media reports. The MDB RBO is analyzed according to institutional design and evaluation criteria proposed by Huitema and Meijerink (unpublished manuscript). We also draw on responses to a small number of questions from semistructured interviews with senior government water managers, which were carried out in 2009 during the first author's $\mathrm{PhD}$ research on integrated water management in the MDB. The responses to questions on the evolution of policies and practices in the MDB, developments in water law, and who are the most influential stakeholders and how they have exerted influence were especially relevant for this article. We have also incorporated detailed comments from two anonymous referees.

The following analysis of the MDB management is divided into four parts. The article begins with a short introduction to the MDB, the evolution of management institutions over the last 20 years, and the drivers for change, including the recent centralization of MDB management authority. Secondly, the political dimension of reform is explored through an analysis of groups and organizations that have promoted or resisted reforms, together with the strategies they have used. Thirdly, the performance of the pre- and post-2007 MDB RBOs are analyzed in terms of cooperation, coordination, accountability, legitimacy, and financing. The article ends with a short concluding section.

\section{CONTEXTUAL INFORMATION}

\section{Socioeconomic and biophysical context}

The Murray-Darling Basin occupies 1,043,000 $\mathrm{km}^{2}$ in southeastern Australia. The MDB has a population of 2.1 million people and supplies about $40 \%$ of the gross value of Australian agricultural production. The MDB spans four Australian states (Queensland, New South Wales, Victoria, and South Australia) and the Australian Capital Territory. River basin organization in the MDB offers an example of federal multilevel governance (compare Morris and De Loë 2016). The MDB boundary is defined by the catchment areas of the Murray and Darling rivers and their many tributaries, together comprising 23 major river valleys (Fig. 1).

The Basin has a dry and highly variable climate, with annual average rainfall varying from less than $200 \mathrm{~mm}$ in arid western regions to more than $1000 \mathrm{~mm}$ in some eastern upland areas. Inflows to rivers ranged from 118,000 gigalitres (GL) in 1956 to less than $6740 \mathrm{GL}$ in 2006. Water use in the Basin expanded substantially from about $4000 \mathrm{GL}$ a year in the mid-1950s to more than $12,000 \mathrm{GL}$ in the 1990 s owing to growth in irrigated agriculture. However, it fell to an average of 8100 GL between $1999 / 2000$ and 2008/2009 owing to dry weather conditions during that decade (MDBA 2010).

Fig. 1. The Murray-Darling Basin.

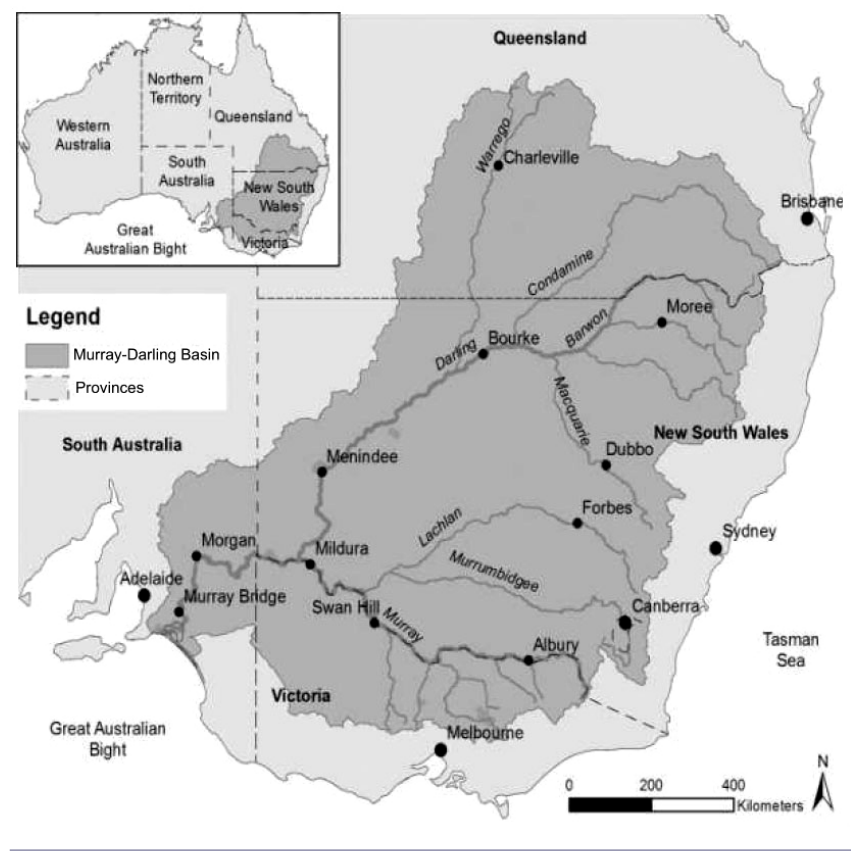

Policy and institutional context

Under Australia's federal system of government, the primary right to own or control and use water is vested with the states and territories (Lucy 2008), and the states manage water allocation, planning, and implementation. The Australian government plays a major role in water policy development and financing. The institutional arrangements in the MDB have evolved through three major stages (Blomquist et al. 2004):

- the 1915 River Murray Agreement allocated water flows of the Murray River and provided for the construction and operation of infrastructure on the river, which benefited the three River Murray states (South Australia, New South Wales, and Victoria);

- the 1992 MDB Agreement extended the scope and structure of the intergovernmental arrangements to the Darling River; and

- further development of integrated catchment-based water resource management in the MDB culminated in the Australian government's Water Act 2007, the 2008 Intergovernmental Agreement on Murray-Darling Basin Reform, and the development of the Murray-Darling Basin Plan, which came into law in 2012.

Until the late 1980 s, most of the emphasis in water management in the MDB was on rural community development-building infrastructure and water supply capacity. By the 1980s, there were increasing concerns about pressures on water resources, and about water pollution and salinity (Smith 2001). In response, a "cap" on surface water use in the MDB was established under the 1992 
MDB Agreement. Available surface water was allocated to the MDB jurisdictions on the basis of the formula set out in the 1992 MDB Agreement, but groundwater use was not capped and continued to increase (MDBC 2006).

During the 1990s, national developments in water policy had an increasing influence on government policy toward the MDB. The traditional goal of supplying water for community development was supplemented by two additional goals. Firstly, there was a new emphasis on economic efficiency and the establishment of water markets to allocate scarce water resources, embodied in the 1994 Council of Australian Governments Agreement (COAG) on water reform. Secondly, there was a growing emphasis on environmentally sustainable development and integrated catchment management in response to land degradation owing to increasing salinity and soil erosion, and declining water quality. These policy goals were extended and consolidated in the 2004 COAG National Water Initiative (NWI) (National Water Commission 2004) and in the provisions of the Water Act 2007, which required the restoration of river basins to sustainable levels of extraction. The main developments in the institutional and management arrangements for the MDB between 1992 and 2012 and further milestones in the implementation of the MurrayDarling Basin Plan until 2019 are summarized in Table 1.

Table 1. Institutional and management developments in the Murray-Darling Basin, 1992-2019.

\begin{tabular}{ll}
\hline \hline Year & Institutional and managerial developments \\
\hline 1992 & $\begin{array}{l}\text { Murray-Darling Basin Agreement replaces 1914 River } \\
\text { Murray Waters Agreement }\end{array}$ \\
& $\begin{array}{l}\text { Introduction of interim cap on Murray-Darling Basin } \\
\text { surface water diversions }\end{array}$ \\
2095 & Basin Salinity Management Strategy adopted \\
2004 & National Water Initiative signed by all basin governments \\
2007 & Water Act 2007 introduced \\
2008 & $\begin{array}{l}\text { Murray-Darling Basin Authority formed; } 1992 \text { agreement } \\
\text { becomes part of Water Act 2007 }\end{array}$ \\
2012 & Murray-Darling Basin Plan becomes law \\
2017 & Five-year report on the effectiveness of the Basin Plan \\
2019 & State water resource plans revised in-line with the Basin \\
& Plan; sustainable diversion limits come into effect \\
\hline
\end{tabular}

\section{THE CHANGING DESIGN OF MURRAY-DARLING BASIN MANAGEMENT INSTITUTIONS SINCE 1992}

Murray-Darling Basin management since 1987 can be divided into two periods; from 1992 to 2006 during the development and implementation of the 1992 MDB Agreement (MDBC 2006), and from 2007 to the present following the 2007 Water Act and the 2008 Intergovernmental Agreement on MDB Reform (COAG 2008). The second period includes the development and implementation of the Murray-Darling Basin Plan, which came into effect in 2012.

In the following sections, institutional arrangements during these two periods are discussed under the following headings:

- Authorities and accountability: the roles, responsibilities, and mandate for action given to the MDB executive and administrative bodies, who they are accountable to, and by what means
- Decision-making: how the views of individual governments and other stakeholders are weighted and how collective choices and decisions relevant to MDB management are made. In a federal system with relatively complex multilevel governance, decision-making rules and procedures are particularly important.

Reference is also made to information collection and provision, financial arrangements, and incentive mechanisms. The rules before and after 2004 are summarized in Table 2 and are discussed in the remainder of this section.

Table 2. Major changes in Murray-Darling Basin management since 2004.

\begin{tabular}{ll}
\hline \hline $\begin{array}{l}\text { Rule types } \\
\text { Before reform }\end{array}$ & After reform \\
\hline $\begin{array}{l}\text { Authority } \\
\text { Joint national and state powers } \\
\text { to manage Murray-Darling } \\
\text { Basin water resources }\end{array}$ & $\begin{array}{l}\text { Australian government authority } \\
\text { to make and enforce the Basin } \\
\text { Plan }\end{array}$ \\
$\begin{array}{l}\text { Aggregation } \\
\text { Consensus decision-making }\end{array}$ & $\begin{array}{l}\text { Greater centralization of powers } \\
\text { with the Australian government }\end{array}$ \\
$\begin{array}{l}\text { Boundaries } \\
\text { Physical boundaries clearly } \\
\text { governments participate in } \\
\text { decision-making. Some } \\
\text { consultation with water users } \\
\text { and third parties }\end{array}$ & No substantial change \\
$\begin{array}{l}\text { Information } \\
\text { Information sharing between } \\
\text { jurisdictions and their } \\
\text { representatives }\end{array}$ & $\begin{array}{l}\text { Greater centralization of } \\
\text { information collection and } \\
\text { provision with Australian }\end{array}$ \\
$\begin{array}{l}\text { Financing } \\
\text { Intergovernmental cost-sharing } \\
\text { formulae }\end{array}$ & $\begin{array}{l}\text { Greater proportion of funding } \\
\text { from the Australian government }\end{array}$ \\
\hline
\end{tabular}

\section{Authorities and accountability under the 1992 Murray-Darling Basin Agreement}

The purpose of the 1992 MDB Agreement was "to promote and co-ordinate effective planning and management for the equitable, efficient and sustainable use of the water, land and other environmental resources of the Murray-Darling Basin" (Commonwealth Parliament 1993). The Agreement included details on the authorities and processes of the MDB Ministerial Council, Commission, and Office; distribution of (available) water between the contracting states; investigation and monitoring; and construction and maintenance of works. Each of the contracting governments agreed to provide for the execution and enforcement of the Agreement in their jurisdiction.

An RBO was established to coordinate activities and organizations in order to implement the Agreement. In the Australian federal system, neither the Australian government nor an RBO can have absolute authority because under the Australian Constitution, state governments (and their agencies) have plenary legislative power to govern resources in their state. Moreover, section 100 of the Constitution restricts the Australian 
government from abridging the right of a state or its residents to the reasonable use of waters or rivers for conservation or irrigation (Gardner et al. 2009).

The RBO included four parts: the Murray-Darling Basin Ministerial Council (the political or policy-making body), the Murray-Darling Basin Commission (executive body), the Commission's Office (administrative body), and the Community Advisory Committee (stakeholder consultative body) (Fig. 2) (MDBC 2008).

Fig. 2. The Murray-Darling Basin (MDB) organization under the 1992 Murray-Darling Basin Agreement.

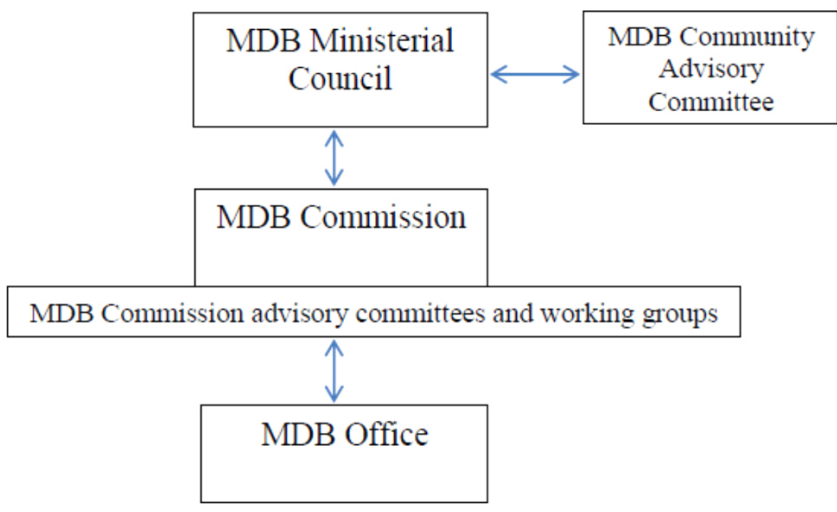

The MDB Ministerial Council was authorized to take decisions on major policy issues of common interest to the contracting governments, and authorization of measures concerning effective planning and management for the equitable, efficient, and sustainable use of the water, land, and other environmental resources of the MDB. This mandate included capital works, studies, and amendments to the Agreement. Management of groundwater was not included in the Agreement. The MDB Ministerial Council included ministers who represented each of the states and the Act, and was chaired by an Australian government minister.

The MDBC was the executive body for developing, coordinating, and implementing measures authorized by the Council. It also advised the MDB Ministerial Council on Basin conditions and resource development, planning, and management. Over time, the Commission's activities expanded into the management of salinity and native fish, interstate water trade, and water policy development. The MDBC worked with state and local governments and catchment management organizations to monitor the quantity and quality of the River Murray system and to assess and carry out works. Catchment management organizations are community-based organizations that were established to implement natural resource management programs, including the National Action Plan for Salinity and Water Quality, and the Natural Heritage Trust, at the catchment scale. Their statutory powers, responsibilities, structures, and capacities vary between jurisdictions and regions. The MDBC was supported and advised by the MDB Office. The Commission and the Office coordinated intergovernmental management, monitoring, and research on the MDB.
The MDBC and its Office were accountable to the MDB Ministerial Council, which was in turn responsible to participating governments. The MDBC was accountable to the Council, and to each of the contracting governments for the monies it received. It was required to report annually on its activities and the achievement of its objectives, policies, and plans.

\section{Authorities and accountability after 2007}

The Intergovernmental Agreement on Murray-Darling Basin Reform was signed on 3 July 2008 by the Australian government, Queensland, New South Wales, Victoria, South Australia, and the Australian Capital Territory (COAG 2008). The 2008 Intergovernmental Agreement on MDB Reform embodied a new phase of Australian government-state relations in the management of the MDB. The provisions of the 2008 Intergovernmental Agreement on MDB Reform are reflected in the Water Amendment Act 2008.

Key provisions in the 2007 Act and the 2008 Act and Agreement are the requirements for the preparation of a Murray-Darling Basin Plan, the allocation of responsibility for the plan to the Australian government, the establishment of the Commonwealth Environmental Water Holder, and the extension of the role of the Australian Competition and Consumer Commission to regulate markets and charges for water in the Basin. The Act also includes provisions for transfer of powers from the Murray-Darling Basin Commission to the Murray-Darling Basin Authority. State governments will make plans for specific water resource areas consistent with the Murray-Darling Basin Plan. The key objectives of these reforms are to improve the efficiency of water use and to return water sources to environmentally sustainable levels of extraction. The revised post-2007 RBO arrangements are summarized in Fig. 3. These arrangements represent a shift from a cooperative federal model to a more centralized prescriptive model.

Fig. 3. The Murray-Darling Basin (MDB) organization after 2007.

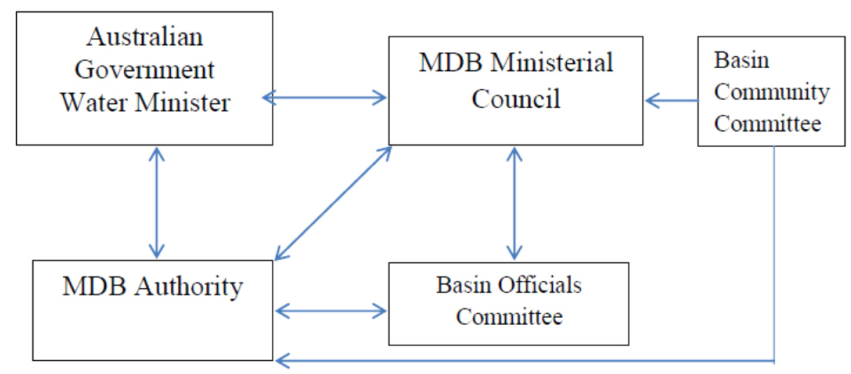

The Murray-Darling Basin Plan provides a more comprehensive management framework and the 1992 Agreement. It sets limits on both surface water and groundwater use, provides for a oneoff adjustment and water entitlements, outlines basin-wide environmental watering arrangements, sets water quality targets, and establishes water trading rules (MDBA 2015a). Substantial authority is concentrated in the hands of the Australian government's minister for water. $\mathrm{He}$ is responsible for deciding whether or not to adopt the Basin plan, and the MDB Authority reports to him. The minister is accountable to the Parliament of Australia. 
The MDB Ministerial Council retains policy and decisionmaking roles for state water shares and the funding and delivery of natural resource management programs set out in the 1992 MDB Agreement. The Murray-Darling Basin Authority is responsible for the preparation, implementation, and monitoring of the Basin plan and for implementing decisions made by the Ministerial Council and officials committee. The Authority takes responsibility for the activities of the former MDBC, including the management of the River Murray, protection of water and environmental resources, and research. The Authority is accountable to the Australian government minister for the Basin plan and is accountable to the Murray-Darling Basin Ministerial Council for matters in which the Council has a policy and decision-making role (MDBA 2016). A Basin Community Committee with a chair and up to 16 other members, including eight water users, provides advice to the MDB Authority and the Ministerial Council.

The Commonwealth Environmental Water Holder is established by the Water Act 2007 to manage the water entitlements purchased by the Australian government for use in environmental conservation. Environmental watering plans for specific catchments are made in consultation with local advisory groups, and watering actions are conducted on an annual basis and are monitored by state and regional organizations (Department of the Environment and Energy 2015a).

The Water Amendment Act 2008 sets out detailed mechanisms for the appropriate Australian government authorities to modify and enforce the Murray-Darling Basin Plan. This represents a switch of powers from the states to the Australian government, although the Act provides for the states to be consulted on changes to the plan, and on water plans submitted under the plan.

\section{Decision-making}

Under the 1992 MDB Agreement, Council decisions could be carried only by the unanimous vote of all ministers present who constituted a quorum (MDB Agreement, Part III, 12). Decisions of the Commission could be made only by resolutions carried by a unanimous vote of the MDBC's president and all of the commissioners (two from each jurisdiction). However, advice by the Commission to the Ministerial Council could be determined on the basis of a majority rather than a unanimous vote.

The MDB Ministerial Council and the MDBC were advised by a Community Advisory Committee that included representatives of local communities and stakeholder groups from throughout the Basin. However, the MDB Ministerial Council was not bound to take account of input from the Community Advisory Committee. An MDBC assessment of community consultation procedures suggested that while the general public was usually satisfied with access to information on the management of the MDB, there was a lower level of satisfaction with opportunities to influence the MDBC's agenda and processes (Chenowyth et al. 2002).

These weaknesses coupled with the limitations of the MDBC's capacity to act quickly in response to drought conditions after 2002 led to proposals for reform, including majority voting, greater openness in Council and Commission proceedings, and an enhanced Community Advisory Committee (Connell 2007). However, under the post-2007 arrangements, the MDB
Ministerial Council continues to operate on the basis of consensus. In addition, the powers of the Council are less than the pre-2008 Council in two respects:

- First, the Council can only agree on policy within the constraints defined by the Murray-Darling Basin Plan, which ultimately has to be approved by the Australian government minister. The minister has to take account of comments by the Council but does not have to implement them.

- Secondly, amendments to the Intergovernmental Agreement by the Council can take effect only on the registration of legislative instrument in Australian government law. This may be disallowed by the Parliament of Australia.

\section{Information collection and provision}

Part V of the Murray-Darling Basin Act 1992 provided for the Commission to coordinate or carry out surveys, investigations, and studies related to works and measures for the equitable, efficient, and sustainable use of water, land, and other environmental resources of the MDB. The Commission was also required to make and record measurements of the flow of the River Murray, diversions from the river and its tributaries, and the volume of stored water, although it substantially relied on data provided by the Basin states. The Basin states were required to inform the Commission about any proposals that could alter the flow, use, or quality of water (Australian Government 1993).

Under the post-2007 management arrangements, the MDBA has similar powers to the MDBC to measure and monitor water resources in the Basin. It has the key task of gathering information and undertaking research required to prepare and monitor the implementation of the Murray-Darling Basin Plan, including sustainable diversion limits and water transfer rules. The Basin states are required to ensure that the Authority has the information needed to monitor compliance with the long-term average sustainable diversion limits set in the Basin plan, including a summary of information on Basin water entitlements contained in state-based registers (Parliament of Australia 2012). The Water Act 2007 also provides for the National Bureau of Meteorology to collect comprehensive, up-to-date water information across Australia, including in the Murray-Darling Basin. This includes a national water account and reports on resource use and availability.

\section{Financial arrangements}

The costs of Basin infrastructure works, monitoring, and research, and other collective action under the 1992 MDB Agreement were shared between participating jurisdictions under various cost-sharing formulae. In 1997, the MDB Ministerial Council agreed on a formula for sharing operating and maintenance costs between the states of $40 \%$ New South Wales, $36 \%$ Victoria, and 24\% South Australia (Haisman 2004). Capital costs were shared equally between the Australian government, New South Wales, Victoria, and South Australia. In 2003, MDB jurisdictions agreed on new funding of A\$500 million over five years to recover and manage water for environmental purposes. The Australian government provided A\$200 million with the remainder shared between the states (New South Wales and Victoria 38\% each, South Australia 22\%, and the Australian Capital Territory $1 \%$ ). These cost-sharing agreements illustrate 
the capacity of MDB jurisdictions to cooperate to address some common problems affecting land degradation and river health.

The Australian government has taken on major new financial responsibilities under the 2008 Intergovernmental Agreement on MDB Reform, including for the purchase of water entitlements and financing state infrastructure projects. The government has purchased about $1360 \mathrm{GL}$ of entitlements (Department of the Environment and Energy 2015b) at the cost of A\$2.3 billion (MDBA 2015b), and has spent A $\$ 2.3$ billion on state infrastructure improvement projects. The Australian Competition and Consumer Commission provides advice to the Commonwealth on water charges and market rules to apply within the MDB, and is responsible for enforcing these rules. The cooperative funding model for MDB Authority infrastructure, monitoring, and research has continued under the post-2007 arrangements, with some variations in the proportion of state government contributions, which reflect changes in the priorities of the ruling governments.

\section{STAKEHOLDERS AND THEIR STRATEGIES TOWARD REFORM}

The main stakeholders who have influenced the post-2007 MDB management reforms are Australian government and state government ministries and departments and water users, especially irrigators. Other important stakeholders are the MDB Ministerial Council, Commission, and Office and their successor, the MDBA, catchment management organizations, and environmental and scientific groups. These stakeholders are heterogeneous groups that include people with differing views on particular issues. Also, the positions of some stakeholders, especially governments, have changed over time.

\section{The Australian government}

In recent years, both major parties in Australian federal politics have supported Australian government takeover of primary responsibility for MDB policy and planning. In response to slow progress with aspects of the Council of Australian Governments 1994 water reforms and the National Water Initiative, the Howard government initiated the reforms in the Water Act 2007. The provisions of the Act, including the Australian government takeover of the lead responsibility for management of the Murray-Darling Basin, relied on Commonwealth trade and commerce, corporations, external affairs, and territories powers (Kildea and Williams 2011).

In his speech introducing the 2007 Water Bill, Minister for Environment and Water Resources Malcolm Turnbull noted that water use in the MDB had increased from $2000 \mathrm{GL}$ in the 1920s to more than $10,000 \mathrm{GL}$ at the end of the 20th century, and that the provisions of the 1992 MDB Agreement had proved insufficient to guarantee water supplies during severe drought conditions such as 2006-2007, when volumes in major basin water storages fell below $15 \%$. The Australian government takeover was supported by the findings of enquiries by the Australian Senate and the Productivity Commission, an independent Australian government agency which reviews and advises the government on microeconomic policy and regulation.

In 2009, the Senate Rural and Regional Affairs and Transport References Committee Inquiry into Implications for Long-Term Sustainable Management of the Murray-Darling Basin System
(Parliament of Australia 2009:xii) recommended that the Australian government work toward complete federal management of the Basin. In the report of its 2009 inquiry into Market Mechanisms for Recovering Water in the Murray-Darling Basin, the Productivity Commission found that the provision of power to the MDBA to develop and enforce a Basin-wide plan for the use of water resources should improve coordination in water planning across the Basin. This would be achieved principally by requiring that all entities manage their Basin water resources in accordance with water resource plans accredited under the Murray-Darling Basin Plan (Productivity Commission 2010).

It is noteworthy that the Murray-Darling Basin Plan focuses only on the use of water resources; the management of land and enforcement of property rights are separate and remain with the states. This is an important decision that limits the scope of the RBO. Thus, water resource protection and water recovery and allocation actions by catchment management organizations and local environmental managers will need to be consistent with state-based land management plans as well as with the Basin plan. Cooperative arrangements between the federal government and other levels of government will still be needed to manage all of the inputs required to achieve environmental outcomes.

The main strategies that the Australian government has used to pursue its reform goals have been the takeover of powers to manage the Basin, as previously discussed, together with financial incentives. The Australian government's Water for the Future program included A $\$ 6$ billion to support improvements in water efficiency through infrastructure investment and A\$3 billion for water entitlement buybacks. The funding for infrastructure investment has subsequently been increased, bringing the total of Australian government support to about A \$13 billion.

\section{State governments}

State government positions in relation to MDB reforms have been informed by self-interest, politics, and pragmatism. The positions and strategies of state ministries and departments in relation to MDB reform have changed over time, but a consistent theme has been their concern with maintaining state autonomy and existing water allocation arrangements. South Australia, the downstream state in the MDB, has sought to maintain downstream flows while the other states have supported diversions, especially for irrigation, and objected to restrictions on consumptive use. But these divisions between upstream and downstream states have been blurred by rivalries among the downstream states and the increasing role of the Australian government, including through financial assistance to the states.

An important factor in persuading the states to accept the MDB "cap" was that they wanted to receive Australian government payments and infrastructure investments. In 2007, the Labour premiers of South Australia, New South Wales, and Queensland supported the Australian government's proposal to take over the leading role in the management of the Basin because their agreement would unlock A $\$ 13$ billion worth of Australian government funding for infrastructure and voluntary buyback while maintaining their access to water. State governments, especially in New South Wales, faced substantial difficulties because they had overallocated entitlements to use water resources, and it was difficult and expensive to reverse this 
overallocation. A large injection of Australian government funds provided a solution. Victoria initially opposed the Australian government proposal but finally agreed to support a modified proposal on the basis that it had an extra five years until 2019 to bring its water plans into compliance with the new Basin plan, and that the Australian Competition and Consumer Commission would oversee water markets.

At the same time, the division between the positions of the Australian government and South Australia on the one hand, and Victoria, New South Wales, and Queensland on the other has strained relations between governments. This, together with cuts to administrative support for the Basin organization and legal challenges to the plan, has led to concerns about whether momentum can be maintained for implementing key elements of the Basin plan, especially the strategy for environmental water (Horne 2014).

\section{Catchment management organizations}

Catchment management organizations were not extensively involved in the reform process and did not have much opportunity to influence it, although they have an important role in implementing aspects of the Basin plan, such as catchment water plans, collection of water information, and monitoring water quality. These organizations have adopted a cautious and somewhat skeptical approach toward the reform, in part because they lack knowledge about the details of the Basin plan, and the implications of the reform for them are unclear.

\section{The Murray-Darling Basin Commission}

The Commission and its Office coordinated intergovernmental management of the MDB under the direction of the MDB Ministerial Council. The Office was able to influence policy development by establishing and maintaining itself as a source of scientifically sound and neutral technical advice. The Office also administered a number of programs to improve the MDB management, as previously discussed.

The states were uncomfortable with some of the reforms and programs promoted by the Commission but went along with them because of growing public demand for action to reverse continuing degradation. The Australian government took the view that the Commission (i.e., the Office) was usurping its role in the field of natural resource management and environmental restoration. The Government reduced the influence of the Commission by channeling new natural resource management program money through the Natural Heritage Trust and the National Action Plan on Salinity and Water Quality directly to state agencies rather than through the Commission (P. Cullen, 2004, personal communication).

\section{Major water users}

The main water user in the MDB is the agriculture sector $(85 \%)$ followed by the water supply industry (13\%) (ABS 2008). Development of agriculture in the Murray-Darling has been substantially assisted by the supply of cheap water through public infrastructure. Recently, farmers have been granted individual transferable water use entitlements.

Irrigators are generally opposed to any changes in current arrangements that could result in any reduction in their water use entitlements or loss of access to cheap water. However, there are some divergences among irrigators. Producers with permanent plantings such as vines or orchards have favored a more restrictive policy on the issue of water entitlements, and in that sense have shared some common ground with environmental interests (Heinmiller 2007). Some crop farmers (cereals, rice) have been prepared to accept temporary reductions in access to water, providing that they can have full access to water entitlements in normal to wet years (Blomquist et al. 2004).

Irrigator groups were skeptical about the Australian government takeover of MDB management powers. Danny O'Brian, CEO of the National Irrigators Council, said the Council did not support a full federal takeover because there was no evidence that shifting management from one group of politicians and bureaucrats to another would improve the operation of the system (Madden 2010). Irrigators organized themselves across the Basin to make strong protests against the first draft of the Murray-Darling Basin Plan because of adverse socioeconomic effects on farming communities and the lack of demonstrated environmental benefits. These protests prompted the Australian government to undertake further socioeconomic and environmental studies and a comprehensive program of community consultation, which led to many revisions in the final version of the plan.

Urban water use in the MDB is a relatively small proportion of the total. The largest cities in the MDB states are on the coast, and outside the MDB catchment areas. Urban water suppliers and municipal authorities in the MDB have relied on consumer demand restrictions to manage water shortages when water storages fall to low levels (Productivity Commission 2008). Urban suppliers can accommodate reduced supplies, providing it does not jeopardize their overall financial situation (Blomquist et al. 2004).

\section{Environmental and scientific groups}

Environmental groups have supported Australian government intervention to provide specific water entitlements and allocations for the environment and to restrain further allocations for irrigation and other extractive uses. Environmental groups have formed an alliance with independent experts, such as the Wentworth Group of Concerned Scientists, in order to press their case for increased environmental allocations. Environmental and scientific groups generally rely on media, lobbying, and submissions to advance their views.

\section{PERFORMANCE UNDER THE PRE- AND POST-2007 MANAGEMENT ARRANGEMENTS}

\section{Cooperation}

The MDB initiative introduced in the mid-1980s and later codified in the 1992 MDB Agreement (and in parallel legislation in the MDB states) was fundamentally based on the concept of "comity." The Water Act 2007 and the 2008 Intergovernmental Agreement on MDB Reform introduced a very substantial change in the philosophy shaping integrated water resource management in the MDB. This is in essence a shift to a "top down" contractual or purchaser provider model.

Comity is a long established concept in international law whereby all parties agree to work for mutually beneficial solutions and avoid beggar-your-neighbor or zero sum strategies (Wanna et al. 2009). At the core of the MDB initiative, there was a belief that cultivating trust between the many different stakeholders was the 
key to progress with water reform. This led to substantial progress on some difficult policy issues despite frequent and intense conflicts between jurisdictions and competing interests.

In order to encourage participants to work together through persuasion rather than competition, all decisions in the first MDB Ministerial Council had to be unanimous. Subsequent history exposed both the merits and limitations of this approach. Coordination was relatively comprehensive across sectors and levels of government, but some contentious issues were not dealt with. On the one hand, there have been significant achievements in cooperative action at the catchment and local level, such as the generally effective implementation of the surface water "cap," the salinity and drainage strategy, and the Living Murray program. There was less progress on issues where one or more states resisted change, such as returning over-allocated catchments in the MDB to sustainable levels of allocation, cross-state water trading, and ensuring the health of river and groundwater systems (National Water Commission 2009).

Major reform of the Murray-Darling Basin management arrangements was prompted by the progressive increase in pressures on the water resources of the Basin coupled with failure of arrangements under the MDB Agreement to handle water scarcity caused by the severe and prolonged drought following 2002. While the MDB Ministerial Council's authorities gave it considerable potential for action, in practice the Council's capacity to act was severely limited for three reasons:

- Firstly, the MDB Ministerial Council members and MDB commissioners represented jurisdictional positions rather than acting in the best interests of the Basin as a whole (Scanlon 2006). This made it difficult for them to take any action that harmed the interests of individual states, such as collective action to deal with the over-allocation of water use entitlements.

- Secondly, the capacity of the Council for decisive action was constrained by the requirement for unanimous voting to pass its resolutions. This requirement resulted in a cautious incremental approach by the Council, and although some valuable programs were introduced and implemented, many hard decisions were avoided (Watson 2008).

- Thirdly, the implementation of MDBC decisions and programs depended on the cooperation and capacity of state agencies, catchment management organizations, and local actors. Contracting states did not fully implement all the decisions made by the Council and the Commission, and the Australian government lacked powers to remedy failures of action by the state governments (Gardner et al. 2009). Moreover, many catchment management and local organizations were short of capacity to implement MDBC programs.

The purchaser-provider model at the heart of the 2008 water reform package is very different and more hierarchical, centralized, and coercive than the previous approach. Under the 2008 legislation, the Australian government has made an overarching Basin plan that in principle can take account of all issues of importance to water management. If a state fails or refuses to develop a satisfactory implementation plan, the Australian government is empowered to act in lieu of the state.
In addition to the legal powers of enforcement contained in the Water Act, the Government provided A $\$ 13$ billion to finance improvements in water efficiency and buyback of water entitlements that could be accessed by complying states.

The purchaser-provider model creates a relationship where the purchaser is contractually dependent on the provider and vice versa. The contracting purchaser, the Australian government, can reject what is provided, but this may be difficult because of political risks when urgent or continued service provision is at stake. The contracted providers, state governments, may have the option to reject the offered deal, but the likelihood of this is reduced because the deal comes with attractive financial incentives, coupled with the threat of further Australian government intervention in their affairs if they do not agree. As a result, the states have eventually accepted the new system and continue to defend or promote their interests in other ways.

While the hierarchical and centralized model has been more effective than its predecessor in delivering a comprehensive and integrated Basin plan, it may not be so effective in the implementation phase. Certainly, effective cooperation between the Australian and state governments, regional catchment management organizations, local governments, irrigators, and environmentalists will be required in order to implement the plan. But both irrigators and environmentalists strongly criticized the draft Murray-Darling Basin Plan, and the states have canvassed options ranging from delayed implementation to possible legal action against the plan. Cooperation is also threatened by concerns across the natural resource management community about the recent emphasis on centrally determined, narrowly focused natural resource management investments, inadequate consultation with regional stakeholders, and declining levels of funding (Robins and Kanowski 2011).

The implementation of the Murray-Darling Basin Plan certainly requires further trust building between key stakeholders across sectors and at different levels of implementation. It remains to be seen how well this will be achieved. The design and structure of the RBO can provide only part of the solution for Basin governance; much depends on effective leadership and supportive cultures in the MDB organizations, good working relationships between key stakeholders, and flexibility of institutions in response to changing conditions and knowledge (Ross and Dovers 2008).

While relationships between key stakeholders could hinder implementation of the Murray-Darling Basin Plan, it seems likely that the Australian government can acquire sufficient water entitlements to achieve, by itself, most of the environmental targets of the plan. The Commonwealth Environmental Water Holder (CEWH) has acquired 2388 GL of water entitlements, and by 30 November 2015, 5143 GL of CEWH environmental water had been delivered to support water-dependent ecosystems in rivers, wetlands, and floodplains of the MDB (Department of the Environment and Energy 2015). The water rights held by the CEWH are especially important during times of hydrological stress when political pressure is often exerted to increase supply to irrigation at the expense of the environment (Banks and Docker 2014). It is likely that the CEWH will emerge as one of the most important water management institutions in the MDB, working with representatives of other jurisdictions and other policy sectors. 


\section{Coordination}

Planning and management in the MDB faces both horizontal and vertical coordination challenges arising from the horizontal separation of policy sectors at each level of government and the vertical separation of policy and administrative functions between different levels of government. Coordination can be broken down into a range of tasks of varying levels of achievement ranging from communication between sectors and governments about individual plans and actions through to joint plans and strategies (Ross 2008). Effective coordination can be defined as a situation in which policies and programs that governments introduce are characterized by minimal redundancy, incoherence, and gaps (Peters 1998).

The complicated multilevel process for policy development, policy coordination, and decision-making in the MDB is summarized in the following assessment:

Policy development [in the MDB] now involves
complicated interactions between a large number of
individuals, groups, organizations and institutions
including governments. The Australian Government and
the States are focal points around which contending
interests arrange themselves, moving from one to the
other as their members make strategic decisions about
alliances and how to best promote their goals or block
those of others. In practice, decisions are not made
through a top-down process but are the product of
complex cycles of interaction in which the participants
have varying degrees of influence but no single one is
dominant. (Connell 2007:180)

Under the new governance framework, objectives, performance requirements, and monitoring and evaluation processes are spelled out in some detail in the Murray-Darling Basin Plan legislation. Effective coordination has been achieved at higher levels of the Australian and state governments as indicated by adoption of the Intergovernmental Agreement on MurrayDarling Basin Reform, although there have been intersectoral disagreements, for example, between agriculture and the environment. Coordination between the high level of government and regional and local governments and stakeholders has been less successful. The imposition of a technocratic solution that is acceptable at higher levels of government comes at the risk of less engagement at regional and local levels, thereby increasing the "implementation deficit." It remains to be seen how much central steering and what incentives will be needed to bring about and maintain effective horizontal and vertical coordination.

\section{Accountability}

Under the MDB Initiative, the Australian government and the states worked together to develop policy. The Ministerial Council introduced audits for the "cap," the Basin Salinity Management Strategy, and the environmental condition of the rivers. These activities complemented the auditing processes undertaken to help implement the 1994 Council of Australian Governments water reforms as part of the National Competition Policy. The Australian government supplied the bulk of project funds to a variety of recipients but usually relied on indirect processes of accountability to influence implementation. The MDBC and its Office provided a reasonably good balance of discretionary powers and accountability, but accountability was somewhat fragmented across different programs and levels of government.
Under the new governance framework, the imposition of a technocratic solution and strong accountability at higher levels of government gives less emphasis to regional and local levels, and risks increasing the "implementation deficit." In response to the new approach encompassed in the Basin plan, some of the states, notably New South Wales, have adopted a minimalist strategy whereby they commit to do what is funded by the Australian government but not much more. In addition, the power of the Australian government to pressure noncooperative states is constrained by the risk that any Australian government that "punished" a state is likely to suffer losses in the following federal election.

\section{Legitimacy}

The high-level coercive approach may have produced a more comprehensive and integrated Basin plan, but this has come at the cost of reduced (input) legitimacy at regional and local levels. This strategy has been criticized for not sufficiently engaging regional and local land and water management organizations and groups. This has damaged goodwill and social capital that was built up over many years work on collaborative natural resource management by imposing a plan developed in isolation by government representatives (Byron 2011, Robins and Kanowski 2011).

These are still early days for the Murray-Darling Basin Plan; full implementation is not due to commence until 2019. It is unclear whether output legitimacy can be achieved under the current model. If output legitimacy means balancing productive and environmental goals of Basin management, the achievement of long-term environmental goals will depend on successful water purchasing and releases for environmental purposes organized by the new Commonwealth Environmental Water Holder.

\section{Financing}

Since 1915, MDB jurisdictions have managed Basin assets and programs on a cooperative basis. This arrangement has succeeded because the Basin jurisdictions have agreed to share management costs. It is unclear whether this successful financing model will continue after funding cuts are made by both the Australian federal and state governments.

\section{CONCLUSIONS}

The 2007 reform of the Murray-Darling Basin policy and management has involved a centralization of powers and functions toward the Australian government. The reform has succeeded in rebalancing water allocations with the introduction of allocation for the environment, and reduced diversion limits. Scientific information on Basin water resources has been consolidated under the Bureau of Meteorology and made widely available. Clear accountability for the implementation of the Murray-Darling Basin Plan rests with the Australian government minister for water. These developments have been supported by a large investment of funds by the Australian government. While this strategy has been successful in persuading state governments to go along with the Australian government "takeover" of MDB management, the implications for the effectiveness of basin management are less clear.

There are some longer term risks to the implementation of the Murray-Darling Basin Plan and the effectiveness of the RBO. While the hierarchical and centralized model has been effective in producing a comprehensive and integrated Basin plan, 
implementation of the plan requires close cooperation and coordination between all governments and water users. State governments have cooperated somewhat reluctantly with the national "takeover" of power, motivated by a substantial financial inducement, and their ongoing cooperation remains to be tested.

Effective coordination has been achieved at higher levels of the Australian and state governments, but coordination between the high level of government and regional and local governments and stakeholders has been less successful. Lines of accountability to the national government are stronger under the new arrangements, but the imposition of a technocratic solution may come at the cost of less accountability and legitimacy at the regional and local level. It is evident that the design and structure of the RBO can provide only part of the formula for effective MDB governance; much depends on effective political leadership, supportive cultures in the MDB organizations, and good working relationships between key stakeholders (Ross and Dovers 2008).

The recent evolution of the Murray-Darling Basin organization does not follow the general direction of river basin management toward more multilevel decision-making together with greater democratic engagement. The Basin organization has evolved toward a more hierarchical and centralized model - a Basin plan under the authority of the national government, produced and monitored by a national agency rather than a coordination body. Stakeholders have been consulted in relation to government policy and management decisions, but most of the consultation on the Basin plan took place after the first draft of the plan was produced, and generally led to changes of detail rather than substance. There were a number of driving forces for this centralization: the establishment of a National Water Initiative with a nationally agreed policy to restore river basins to sustainable levels of extraction, the political difficulty faced by the state governments in reversing the overallocation of water resources, the millennium drought and its effects, political expediency on the part of the Australian government and state governments, and a major injection of Australian government funding. The extent of hierarchy and centralization should not be overstated because state governments remain responsible for catchment water plans, and some decentralized elements remain in place, such as land use planning and arrangements to monitor and maintain water quality. Further swings in the centralizationdecentralization pendulum could be initiated by environmental, economic, social, or political change.

Politics has an important influence on the direction and trajectory of change in the MDB RBO. The 2007 package of reforms was driven by the political expediency of a large investment of funds for rural water resources infrastructure and water allocation buyback in an election year. This investment gave state governments a major incentive to accept the Australian government proposals without changing their underlying motivations or directions. Political negotiation will continue to play an important part in the evolution of the RBO. The full details of the Murray-Darling Basin Plan, including changes needed to meet reduced diversion limits consistent with the plan, and cooperative arrangements for sharing environmental water will not become clear until the states deliver revised catchmentbased water plans in 2019. Contributions from MDB governments to the administration of the Basin plan have fluctuated along with changes of government, and the formula for ongoing financing of the Murray-Darling Basin organization has not been settled (Hart 2015).

Looking to the future, it is not clear whether greater vertical or horizontal policy coordination will be achieved under the more centralized MDB water governance model. It is not clear whether state agencies will push through water reform and reallocation required by the plan, or whether irrigation communities will convince them to argue for changes in the balance between consumptive and environmental water allocations. If implementation of the Murray-Darling Basin Plan is diverted or delayed, the Commonwealth Environmental Water Holder can play a major role in securing and coordinating environmental water supplies. If the CEWH remains in place, this institutional innovation merits attention from international water managers and may prove to be the most significant element in the current phase of the MDB reform.

Responses to this article can be read online at: http://www.ecologyandsociety.org/issues/responses. $\mathrm{php} / 8664$

\section{LITERATURE CITED}

Australian Bureau of Statistics (ABS). 2008. Water and the Murray-Darling Basin - a statistical profile, 2000-01 to 2005-06. Canberra, Australia. [online] URL: http://www.abs.gov.au/ ausstats/abs@.nsf/mf/4610.0.55.007

Australian Government. 1993. Murray-Darling Basin Act 1993. [online] URL: https://www.comlaw.gov.au/Details/C2004A04593/ Download

Banks, S. A., and B. B. Docker. 2014. Delivering environmental flows in the Murray-Darling Basin (Australia)-legal and governance aspects. Hydrological Sciences Journal 59(3-4):688699. http://dx.doi.org/10.1080/02626667.2013.825723

Biswas, A. K. 2004. Integrated water resources management: a reassessment. Water International 29:398-405. http://dx.doi. org/10.1080/02508060408691794

Blomquist, W., A. Dinar, and K. Kemper. 2004. Comparison of institutional arrangements for river basin management in eight basins. Washington Research Working Paper 3636. World Bank, Washington, D.C., USA.

Byron, N. 2011. What can the Murray-Darling Basin Plan achieve? Will it be enough? Pages 385-398 in D. Connell and R. Quentin Grafton, editors. Basin futures. ANU Press, Canberra, Australia.

Chenoweth, J. L., S. A. Ewing, and J. F. Bird. 2002. Procedures for ensuring community involvement in multijurisdictional river basins: a comparison of the Murray-Darling and Mekong River Basins. Environmental Management 29(4):497-509. http://dx.doi. org/10.1007/s00267-001-0029-8

Commonwealth Parliament. 1993. Murray-Darling Basin Agreement 1992. Act 38. Parliament of Australia, Canberra, Australia. 
Connell, D. 2007. Water politics in the Murray-Darling Basin. Federation Press, Annandale, NSW, Australia.

Connell, D., and R. Q. Grafton. 2011. Water reform in the Murray-Darling Basin. Water Resources Research 47(12). http:// dx.doi.org/10.1029/2010wr009820

Council of Australian Governments (COAG). 2008. Agreement on Murray-Darling Basin reform. Canberra, Australia.

Department of the Environment and Energy. 2015a. About Commonwealth environmental water. Australian Government, Canberra, Australia. [online] URL: https://www.environment. gov.au/water/cewo/about-commonwealth-environmental-water

Department of the Environment and Energy. 2015b. Progress of water recovery under the Restoring the Balance in the MurrayDarling Basin program. Australian Government, Canberra, Australia. [online] URL: https://www.environment.gov.au/water/ rural-water/restoring-balance-murray-darling-basin/progress-waterrecovery

Gardner, A., R. Bartlett, and J. Gray 2009. Water resources law. Lexis Nexus, Chatswood, NSW, Australia.

Haisman, B. 2004. Murray-Darling River Basin case study, Australia. Background paper. [online] URL: http://siteresources. worldbank.org/INTSAREGTOPWATRES/Resources/ Australia_MurrayDarlingFINAL.pdf

Hart, B. T. 2015. The Australian Murray-Darling Basin Plan: challenges in its implementation (part 2). International Journal of Water Resources Development 32(1).

Heinmiller, T. 2007. The politics of cap and trade policies. Natural Resources Journal 47:445-467.

Horne, J. 2014. The 2012 Murray-Darling Basin Plan - issues to watch. International Journal of Water Resources Development 30 (1):152-163. http://dx.doi.org/10.1080/07900627.2013.787833

Huitema, D., E. Mostert, W. Egas, S. Moellenkamp, C. PahlWostl, and R. Yalcin. 2009. Adaptive water governance: assessing the institutional prescriptions of adaptive (co-) management from a governance perspective and defining a research agenda. Ecology and Society 14(1):26. [online] URL: http://www.ecologyandsociety. org/vol14/iss1/art26/

Kauffman, G. J. 2015. Governance, policy, and economics of intergovernmental river basin management. Water Resources Management 29(15):5689-5712. http://dx.doi.org/10.1007/ $\underline{\text { s11269-015-1141-5 }}$

Kemper, K., A. Dinar, and W. Blomquist. 2005. Institutional and policy analysis of river basin management decentralization. World Bank, Washington, D.C., USA.

Kildea, P., and G. Williams. 2011. The Constitution and the management of water in Australia's rivers. Sydney Law Review. 32:595-616.

Lucy, J. 2008. Water regulation: the laws of Australia. Thomson Reuters, Sydney, Australia.

Madden, J. 2010. 'Abbott mauled for talk of Murray-Darling takeover.' The Australian 16 January 2010.
Molle, F. 2009. River-basin planning and management: the social life of a concept. Geoforum 40(3):484-494. http://dx.doi. org/10.1016/j.geoforum.2009.03.004

Morris, M., and R. C. De Loë. 2016. Cooperative and adaptive transboundary water governance in Canada's Mackenzie River Basin: status and prospects. Ecology and Society 21(1):26. http:// dx.doi.org/10.5751/ES-08301-210126

Mostert, E. 2003. Conflict and co-operation in international freshwater management: a global review. International Journal of River Basin Management 1(3):267-278. http://dx.doi. org/10.1080/15715124.2003.9635212

Murray-Darling Basin Authority (MDBA). 2010. Guide to the proposed basin plan: Volume 1: Overview. Canberra, Australia.

Murray-Darling Basin Authority (MDBA). 2015a. Basin plan implementation. Canberra, Australia. [online] URL: http://www. mdba.gov.au/basin-plan/whats-basin-plan

Murray-Darling Basin Authority (MDBA). 2015b. Towards a healthy, working Murray-Darling Basin: basin plan annual report 2013-14. Canberra, Australia.

Murray-Darling Basin Authority (MDBA). 2016. Governance. Canberra, Australia. [online] URL: http://www.mdba.gov.au/ about-us/governance

Murray-Darling Basin Commission (MDBC). 2006. MurrayDarling Basin Agreement. Canberra, Australia.

Murray-Darling Basin Commission (MDBC). 2008. Review of implementation: report of the independent audit group 2006-07. Canberra, Australia.

National Water Commission. 2004. Intergovernmental agreement on a national water initiative. Canberra, Australia. [online] URL: http://nwc.gov.au/ data/assets/pdf file/0008/24749/IntergovernmentalAgreement-on-a-national-water-initiative.pdf

National Water Commission. 2009. Australian water reform 2009: second biennial assessment of progress in implementation of the National Water Initiative. Canberra, Australia.

Parliament of Australia. 2009. Implications for long-term sustainable management of the Murray Darling Basin system. Canberra, Australia.

Parliament of Australia. 2012. Water Bill 2007, explosion memorandum. [online] URL: https://www.comlaw.gov.au/ Details/C2007B00164/Download

Peters, G. 1998. Managing horizontal government: the politics of coordination. Research Paper Number 21. Canadian Centre for Management Development, Ottawa, Ontario, Canada.

Productivity Commission. 2008. Towards urban water reform: a discussion paper. Melbourne, Australia.

Productivity Commission. 2010. Market mechanisms for recovering water in the Murray-Darling Basin. Melbourne, Australia.

Robins, L., and P. Kanowski. 2011. Crying for our country: eight ways in which 'Caring for our Country' has undermined Australia's regional model for natural resource management. 
Australasian Journal of Environmental Management 18(2):88-108. http://dx.doi.org/10.1080/14486563.2011.566158

Ross, A. 2008. Australia. Pages 289-310 in A. Jordan and A. Lenschow, editors. Innovation in environment policy: integrating the environment for sustainability. Edward Elgar Cheltenham, $\mathrm{UK}$.

Ross, A., and S. Dovers. 2008. Making the harder yards: environmental policy integration in Australia. Australian Journal of Public Administration 67(3):245-260. http://dx.doi.org/10.1111/ j.1467-8500.2008.00585.x

Scanlon, J. 2006. 100 years of negotiation with no end in sight where is the Murray-Darling Basin Initiative leading us? Keynote Address, Environment Institute of Australia and New Zealand Conference. Adelaide, Australia.

Schlager, E., and W. Blomquist. 2000. Local communities, policy prescriptions, and watershed management in Arizona, California, and Colorado. IASCP Conference Constituting the Commons: Crafting Sustainable Commons in the New Millennium. Bloomington, Indiana, USA.

Smith, D. 2001. Water in Australia. Oxford University Press, Melbourne, Australia.

Teclaff, L. A. 1996. Evolution of the river basin concept in national and international water law. Natural Resources Journal 36:359-391.

Wanna, J., J. Phillimore, A. Fenna, and J. Harwood. 2009. Common cause: strengthening Australia's cooperative federalism. Final report to the Council for the Australian Federation. Council for the Australian Federation, Melbourne, Australia.

Watson, A. 2008. The Howard-Turnbull National Plan for Water Security of January 2007: rescue or rejection? Economic Papers 27(2):146-159. http://dx.doi.org/10.1111/j.1759-3441.2008.tb01033. 